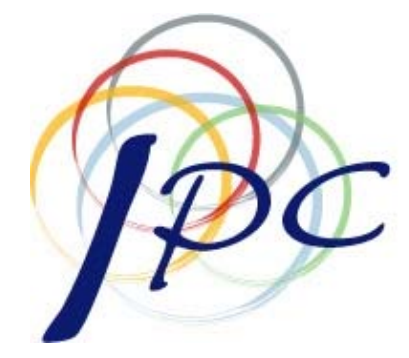

International Policy Center

Gerald R. Ford School of Public Policy University of Michigan

IPC Working Paper Series Number 57

THE MULTILATERAL TRADING SYSTEM

Robert Stern

Octoberber 2007 


\title{
THE MULTILATERAL TRADING SYSTEM
}

\author{
Robert M. Stern \\ University of Michigan
}

\begin{abstract}
This paper traces the evolution of the global trading system from the 19th century to the present-day GATT/WTO arrangements, calling attention to the key roles of reciprocity and non-discrimination and taking note of how the system is now challenged by the new paradigm of global market integration. The main features of the WTO are described, the boundaries of the WTO identified, and how the expansion of these boundaries may result in the over-extension and weakening of the effectiveness of the WTO.

Prepared for Trade Policy for Development Executive Course, Columbia University, School of International and Public Affairs (SIPA) and World Bank Institute (WBI), Columbia University, April 30-May 11, 2007.
\end{abstract}

April 2, 2007

Address correspondence to:

Robert M. Stern

Gerald R. Ford School of Public Policy

University of Michigan

Ann Arbor, MI 48109-3091

Tel. 734-764-2373

Fax 734-763-9181 


\section{THE MULTILATERAL TRADING SYSTEM \\ Robert M. Stern \\ University of Michigan}

\section{Introduction}

In this paper, I first trace the evolution of the global trading system from the 19th century to the present-day GATT/WTO arrangements, calling attention to the key roles of reciprocity and non-discrimination and taking note of how the system is now challenged by the new paradigm of global market integration. In Sections III and IV, the main features of the WTO are described, the boundaries of the WTO identified, and how the expansion of these boundaries may result in the over-extension and weakening of the effectiveness of the WTO. Section V concludes.

\section{The Global Trading System: Yesterday and Today ${ }^{1}$}

"I don't think they play at all fairly," Alice began in a rather complaining tone, "and they all quarrel so dreadfully one can hardly hear oneself speak - and they don't seem to have any rules in particular; at least, if there are, no one attends to them..." Lewis Carroll, Alice's Adventures in Wonderland, p. 112

To a reader in the 19th century, that might well have seemed a fair description of global trading relations at the time rather than of a game of croquet in the Queen of Hearts court. It was only in the course of the 19th century that the beginnings of some order, as we know it today, began to emerge. Industrialization was taking hold in several countries, and it generated an intensified search for foreign markets and sources of supply. Governments in Europe were faced with calls to lower tariff barriers on imported inputs and to negotiate reductions in tariffs protecting foreign markets. But in a nationalistic world of vying states - as it still is today - governments were not about to ease access to their markets in the absence of some quid pro quo.

The way forward was found in the adoption of two instruments of policy - reciprocity and non-discrimination - which set off a wave of trade liberalization. These two ideas enabled

\footnotetext{
${ }^{1}$ This section has been adapted from Brown and Stern (2007).
} 
countries to surmount their innate distrust of each other and to engage in mutually beneficial and generalized reductions in tariff barriers. Reciprocity - meaning contingent and equivalent concessions - assuaged the fear of governments that they might not be receiving at least as much from others as they were giving themselves, and non-discrimination reassured them that they were enjoying the same treatment as had been won by other competing states. Neither of these ideas was a sudden intellectual invention; they had long been known in human affairs. But their application to trade relations was comparatively new and did much to advance global trade liberalization.

Historians usually identify the signing of the Anglo-French Treaty of 1860 as the landmark that signaled the new era of trade relations. Besides the need for a political gesture of friendship, the immediate cause of the signing of the Treaty was a decision by the French government to follow Britain's policy of trade liberalization. The French leaders were persuaded at the time by the popular, but mistakenly simplistic and mono-causal, belief that Britain's superior industrial performance owed much to its free trade policy. However, in undertaking to reduce tariffs on British manufactures, the French government sought some concession from Britain in order to win the support of its export interests in getting the lower tariffs passed through Parliament. Although Britain had already nailed the flag of free trade to its mast - and firmly, but exceptionally, believed that others in their own interest should also reduce their tariffs unilaterally - it accommodated the French political need. ${ }^{2}$ Further, when other European countries anxiously sought comparable access to the French market, France offered them the same tariff rates that it had set for Britain. The inclusion of such a most-favored-nation (MFN) clause in commercial treaties thereafter became common practice among the European states. It also had the advantage of preventing treaties from being in a constant state of flux with tariff schedules having repeatedly to be renegotiated bilaterally.

\footnotetext{
${ }^{2}$ For a full account of the Anglo-French negotiations, see Hinde (1987). For a history of multilateral trade relations over the period 1850 to 2000, see Brown (2003).
} 
What emerged in industrializing Europe from the struggle of countries to gain market access for their exports of manufactured goods was a network of bilateral, commercial treaties linked together through the MFN clause. While this was a step toward more predictable trade relations, however, the system was not notable for its stability. Apart from Britain - which adhered with almost religious fervor to free trade - most European countries found their treaty obligation hard to live with. After a drift toward freer trade in the 1850s and 1860s, most countries later assumed more protectionist stances. Commercial treaties were frequently denounced or renegotiated, and some lengthy and bitter trade wars broke out. Still, while every country valued the freedom to make unilateral decisions about its national trade barriers, all were driven reluctantly to accept constraints on their behavior in order to gain access to others' markets.

The outbreak of WWI in 1914 and the political upheaval engendered in its aftermath disrupted trade relations for some years. Nevertheless, in the peace conferences following the war, the avowed goal of governments was to restore the pre-1914 order in international monetary, financial, and trade relations. But economic conditions militated against a restoration of the minimal levels of mutual trust necessary for agreements. In the unstable monetary conditions of the early 1920s, countries engaged in currency depreciations that were seen by others as competitive and that, in line with economic thinking of the time, made the negotiation of tariff reductions pointless. For a while, in the later 1920s, restoration of the gold standard made the outlook appear more hopeful for trade relations. But the differences in tariff levels between the high and low tariff countries were sizable, and governments could not agree on a common formula for tariff cutting. The onset of the Depression in the 1930s and the early responses to it, with tariff increases and currency devaluations, put an end to any hopes for more normal trade relations.

Some countries, led by Germany, resorted to bilateral barter or clearing arrangements that were necessarily discriminatory. Others, like Britain, sought to revive trade through the creation 
of preferential trading areas. In these circumstances of worldwide inadequacies in domestic demand, trade relations largely ceased to be conducted within a multilateral framework based on non-discrimination.

It is notable that the United States played virtually no part in the evolution of trade relations before WWI and remained largely aloof from international trade affairs in the inter-war years. American manufacturing and marketing skills had become internationally evident as early as the 1890s, but the United States remained for many years principally an exporter of primary commodities. It was fortunate that agricultural exports generally met with low trade barriers before WWI, so there were few restraints on the U.S. pursuit of a high tariff policy on imported manufactures. Indeed, the U.S. Congress could then interpret reciprocity as the negotiation of reductions in foreign tariffs under the threat of increases in American tariffs. MFN treatment was also offered only conditionally so that to qualify for a new MFN tariff rate, all trading partners had to offer equivalent tariff reductions.

However, by the 1920s the interest of U.S. manufacturing industries in foreign markets had grown substantially with the share of manufactures having risen to nearly two thirds of total exports. A latecomer in the world of trade relations, it was only then that the United States began gradually to accommodate itself to the accepted international norms. With the adoption of the Fordney-McCumber Tariff Act in 1922, the principle of unconditional MFN treatment was adopted. And in 1934, the passage of the Reciprocal Trade Agreements Act made reciprocity understood as equivalence in concessions - the accepted means of gaining improved access to foreign markets.

The New Era of the General Agreement on Tariffs and Trade (GATT) and the World Trade Organization (WTO)

Following WWII, which ended in 1945, the United States launched its grand design to establish an orderly multilateral framework for international monetary, financial, and trade relations. The ideas of non-discrimination and reciprocity again became central to the global arrangements for 
trade. But now, they were formally embodied in a multilateral agreement, the General Agreement on Tariffs and Trade (GATT). Two factors reinforced the great importance given by U.S. policy makers at the time to the principle of non-discrimination. One was the conviction of the Roosevelt Administration's Secretary of State, Cordell Hull, that the trade discrimination practiced internationally in the 1930s exacerbated the bitter political rivalries in a period that had finally terminated in war. The other was the more commercial reason that U.S. manufacturers particularly resented the British imperial preferences erected in the early 1930s.

The ideas of non-discrimination and reciprocity have contributed substantially to the progressive reduction of trade barriers on manufactured goods among the core industrialized countries, including North America, Western Europe, and Japan, since the end of WWII. The core countries, until very recently, dominated trade relations within the framework of the GATT, and their central focus was on the reduction of industrial tariffs. The degree to which these tariffs have been reduced can be seen for selected countries in Figure 1 for the period from 1913 to the conclusion of the Uruguay Round. In the early years of the post-WWII GATT negotiating rounds, these tariff reductions were negotiated bilaterally on a reciprocal basis. Later, in the Kennedy Round in the 1960s, reciprocity was expressed in the adoption of a common tariff formula that replaced or supplemented bilateral negotiations. In principle, the core countries likewise adhered largely to non-discrimination in their trade with each other. But, subsequently, in practice, they deviated substantially in the 1970s and 1980s by resort to measures outside the framework of the GATT. These measures mainly took the form of voluntary export restraints or orderly marketing agreements. While their incidence fell more on Japan and some of the newly industrializing countries in East Asia and elsewhere, this evasion of GATT rules became so prevalent that it seriously undermined the respect for the system on which its existence depended. It was partly for this reason that governments during the Uruguay Round negotiations (19861993) agreed to eschew these practices and so reaffirm adherence to non-discrimination. 
Thus, up to and even including the Uruguay Round, it could be fairly said that the ideas of reciprocity and non-discrimination largely shaped international trade relations. But events brought about changes during and after the Uruguay Round. Reciprocity lost some of its relevance and clarity as a guiding principle; and, in the face of the proliferation of free trade agreements (FTAs), non-discrimination in trade relations among states appeared to fade into the background.

\section{Reciprocity and the Changing Character of Trade Negotiations}

Two changes taking place during and since the Uruguay Round have muddied the nature of reciprocity as an idea guiding multilateral trade relations. The first is that, at the behest of the industrial countries, the content of trade negotiations has been substantially broadened; and the second is that the developing countries - thanks largely to their emergence as significant exporters of manufactures - have become influential participants in these negotiations.

Among the major industrial countries, the negotiation of improved market access for service industries and for capital remained based on a clear recognition of reciprocity. Countries agreed to a mutual widening of markets, yielding potential advantage to producers and investors on all sides. In this regard, even the new Uruguay Round agreement on the protection of intellectual property rights (IPRs) only reaffirmed a mutually advantageous form of cooperation that had long been in place.

For the developing countries, however, the question of reciprocity was more complex and uncertain. Developing countries had earlier sought a special status within the GATT, claiming that the industrial countries should reduce their trade barriers to the developing countries in line with the principle of non-discrimination, but without reciprocity by the developing countries. The exceptional status of the developing countries was taken further in the 1970s when the industrial countries introduced the Generalized System of Preferences; and it was also given formal recognition during the Tokyo Round in the late 1970s when clauses relating to Special and 
Differential Treatment were incorporated into the GATT. Further, particular groups of developing countries have been given additional, preferential access to industrial countries' markets. The other side of the coin was that the industrial countries felt free to disregard the spirit of the GATT whenever it proved politically expedient to do so. They did not hesitate to practice extensive discrimination against specific exports from developing countries, most egregiously when they imposed restrictions on textiles and apparel in the 1960s that burgeoned into the Multi-Fibre Arrangement (MFA).

Before the launching of the Uruguay Round in 1986, however, these unequal relations had begun to change. Many developing countries had made progress in modernizing their economies through industrialization; and they were all influenced, in varying degree, by the worldwide shift in beliefs about economic policy that, among other things, favored more outward-oriented growth. Indeed, several developing countries had unilaterally lowered their trade barriers and most had become members of, or sought membership in, the GATT.

During and after the Uruguay Round, some “rebalancing” in trade relations began to take place, though it remains highly controversial whether the negotiations satisfied the condition of reciprocity. While developing countries generally did not fully reciprocate in tariff reductions, they agreed, in principle, to the opening up of market access to service industries and to limitations on the conditions that could be imposed on foreign direct investment (FDI). These were both concessions that appeared to largely benefit producers and investors in the industrial countries. When the new international rules on IPRs were added to the list, the grounds for questioning the reciprocal character of the negotiations appeared substantial to many observers.

But there is another and less obvious reason why the idea of reciprocity has lost much of its clarity. This is because the Uruguay Round also gave weight to rules - like those relating to subsidies and FDI - that, while certainly bound up with issues of market access, also impinged directly on domestic policies and practices. Together with revisions of domestic laws and regulations required by the liberalization of the service industries, these initiated what some 
commentators have dubbed the "deeper integration" of markets. They marked the beginning of a new development in trade relations in which actual or proposed trade rules could penetrate more deeply into the management of national economic and social affairs. ${ }^{3}$ Some of the issues later raised by the industrial countries for inclusion in the Doha Round negotiations have borne the same stamp.

While some developing countries may have tacitly accepted these changing rules, others have voiced serious misgivings. As in all countries, the desire to protect entrenched domestic interests for internal political reasons has doubtless been an active consideration. But there are other, more valid reasons. Of central concern are the limitations that these changes imposed on the development policies that these countries were pursuing. Since the early years after WWII, most developing country governments have used their powers to establish national firms in nontraditional sectors. They have created investment opportunities for the domestic business community (or political elite) through the use of a range of measures including tariffs, subsidies in one form or another, quantitative restrictions, and limitations on foreign investment. There is considerable concern accordingly that the freedom to pursue such development policies has been jeopardized by some of the rules adopted in the Uruguay Round.

Some of these new rules were apparently extending the principle of national treatment beyond its traditional, and limited, meaning through added restrictions on the freedom of governments to discriminate in favor of national firms by means of domestic measures. In effect, the leading industrialized country governments were collectively seeking to create an international framework of rules and procedures within which their own markets could be more closely integrated with each other. It was, in more popular terms, to establish a "level playing field” in which the firms of each country would ideally compete everywhere on the same terms. The incipient framework drew on the ideas that guided the industrialized countries in the

\footnotetext{
${ }^{3}$ See Whitman (2004) for a discussion of the issues involving the deeper integration of markets, including pertinent references to the writings of Sylvia Ostry and others.
} 
management of their own domestic markets, and in particular, on those of the leading power, the United States.

This represents a new paradigm in trade relations. It is advocated by those who lean toward a cosmopolitan view of the global economy, one that sees the emergence of an increasingly integrated world market governed by common rules that regulate transactions in this single market. It is a view that coincides with exporting interests, and especially those of multinational corporations. But almost all countries also have national aims that they are not willing to surrender in order to accommodate their trading partners. Some of these aims are rightly dismissed by cosmopolitan proponents as essentially being obstructive rent-seeking activities, agricultural protectionism and antidumping measures being cases in point. But, it needs to be understood that there is a global diversity in aims and policies. Many of these aims and policies have deep roots in national societies, and it can be argued that they should therefore be afforded legitimacy. This is a reality that is reflected in the historically more familiar view of the world as composed of separate nation states, each with its own national market. In this view, it is for each country to decide - in the light of its own social norms and economic aims - how far it wants to adjust its own domestic laws and practices in order to accommodate its trading partners and to gain a comparable adjustment from them. ${ }^{4}$ It is a view that has long been the basis for achieving the reciprocal liberalization of trade.

\section{Establishing the World Trade Organization (WTO) ${ }^{5}$}

The World Trade Organization (WTO) was created in 1995. It is the successor to, and incorporates within it, the GATT, which as already noted, was a treaty among Western market economies that came into effect at the end of WWII. In the GATT, member countries agreed to rules about when they may increase trade barriers, especially tariffs, in order to prevent them from using trade policies that harm other countries. The GATT was also a forum for negotiation

\footnotetext{
${ }^{4}$ See Whalley (2005) for a perceptive analysis of how different social values might interact and change in the process of increasing international economic interdependence.

${ }^{5}$ This section has been adapted from Deardorff and Stern (2002).
} 
to reduce trade barriers. As noted in Table 1, the GATT oversaw eight rounds of multilateral trade negotiations, culminating in the Uruguay Round that created the WTO. As a consequence, as already noted in Figure 1, average tariffs on manufactures have been reduced to relatively low levels. The WTO also took on issues that GATT had not covered, including trade in services, tariffication in agriculture, and intellectual property protection. In 2001, the WTO inaugurated a further round of multilateral trade negotiations that was entitled the Doha Development Agenda in ostensible recognition of the objective of focusing trade liberalization to enhance the interests of the developing countries. The WTO is thus designed to continue the move toward freer trade that was started under the GATT, but the so-called Doha Round is currently in limbo because of unresolved differences in the negotiating positions of its member countries.

The most important change in the WTO, compared to the GATT, may be its dispute settlement mechanism (DSM). The GATT permitted countries to complain against other countries for violating its rules. Each complaint was handled by a "panel” of experts who issued a report that, if adopted unanimously by GATT members, would require the offending party to either change its behavior or be subject to sanctions. However, unanimity meant that the offending party could block a report, in effect giving every country veto power over findings against itself. The surprise was that this ever worked at all, which it did.

The WTO reversed this bias, requiring instead a unanimous decision to block a report, and it therefore made the DSM much more effective. It also made other improvements, including the right to appeal. The various stages of the DSM are depicted in Figure 2. The intent was to provide viable enforcement for WTO rules, and it appears to have worked. Thus, it can be seen in Figure 3 that the DSM has been used much more often than under the GATT. The numbers of DSM complaints and dispositions from 1995-2005 are shown in Figure 4. The percentages by complaining and responding country are indicated in Figure 5. The United States and the European Community have been involved in the most DSM actions, but several other countries have been major users as well. Just as important, large countries such as the United States, have 
stopped going outside the GATT with their most important complaints.

Inevitably, however, the DSM has not worked to everyone's satisfaction. The WTO restricts policies that harm other countries, not only deliberately, but also inadvertently, as when policy restricts the options of another country's citizens. A contentious example was the "shrimp-turtle" case. A U.S. law protected sea turtles from death in the nets of shrimp fishermen by prohibiting imports of shrimp caught without "turtle exclusion devices" (TEDs). Since it is impossible to tell from looking at a shrimp how it was caught, the law restricted imports from certain countries. These countries took the case to the WTO, which decided against the United States. In effect, this decision struck down U.S. law, an intrusion into sovereignty that offended environmentalists and others. There have been other, similar examples. ${ }^{6}$

The potential of the WTO to intrude in national affairs was also increased by its expanded coverage. This can be seen in Table 2, which indicates the scope of the WTO regime. The GATT was limited to trade in goods, even excluding certain sectors such as agriculture and textiles/apparel. The latter was covered instead by the GATT-sanctioned Multi-Fibre Arrangement (MFA), restricting developing-country exports to developed countries. The WTO changed all that, or at least it promised to. The Uruguay Round scheduled the elimination of the MFA, though the most difficult liberalization was postponed ("backloaded") ten years. First steps were also taken in agriculture, converting existing NTBs to tariffs (tariffication) so as later to negotiate them downward. And trade in services was covered in a parallel agreement to the GATT, the General Agreement on Trade in Services (GATS).

The WTO also expanded to new areas. Most prominent is the TRIPS (Trade Related Intellectual Property) Agreement covering intellectual property - primarily patents, copyrights, and trademarks. In addition, the WTO includes (as the GATT had before, actually) some small

\footnotetext{
${ }^{6}$ The details of the DSM cases and decisions can be found on the WTO official website [www.wto.org]. See also Devereaux, Lawrence, and Watkins (2006) for a description and analysis of a number of important case disputes involving the United States, including hormone-treated beef, bananas, film, steel, cotton, and genetically modified organisms (GMOs)
} 
ways that countries may use trade policies for environmental purposes. However, the one area much discussed - where the WTO has not been extended is labor standards and rights. This is the case despite the pressures from many interest groups in developed countries favoring the use of trade policies for this purpose. The resistance from the developing world, including corporations who employ labor there, has prevented labor standards from even being discussed in the WTO.

\section{Whom Does It Help or Hurt?}

With its expanded role, the WTO potentially affects many groups. But fundamentally it is still, like the GATT, a force for increased trade, and thus for much of globalization. The WTO has not, yet, done much on international capital movements, although its agreement on financial services will lower transactions costs for movements of financial capital. But it has done much to facilitate international trade. Those who gain and lose from the WTO, then, are also those who gain and lose from globalization.

That is, as in the case of globalization, the reduction of trade barriers will bring about the increased movement of goods and capital across national borders and international markets will become more integrated. Participants in domestic markets will find themselves either competing with their counterparts in foreign markets, taking advantage of them, or both. Consumers in particular will stand to gain. That is, everybody in a country stands to gain from trade in their role as consumers of goods and services. For many reasons - including comparative advantage, economies of scale, increased competition, and access to a greater variety of products - a country's average consumer, with an average income, is better off with trade than without. ${ }^{7}$ That is, the average person's income will buy a larger, more desirable bundle of goods and services with trade than without, increasing their material standard of living. This proposition, called the

\footnotetext{
${ }^{7}$ This statement is literally correct only if the word "average" refers to the simple arithmetic mean of incomes - that is, total income divided by total population. Given the very skewed distribution of income, this does not necessarily mean that the majority of consumers are better off, since in principle the rich could enjoy a disproportionate share of the gains. However, in practice the vast majority of consumers are likely to gain from trade, the losers being only the small minority whose incomes fall disproportionately due to direct competition from imports.
} 
"gains from trade," has been shown theoretically in all sorts of economic models. With only a few exceptions - which economists generally view as unlikely to reverse the broad conclusion in practice - it applies to all countries comparing trade to not trading at all. The argument extends to further degrees of openness, as well as to other kinds of openness such as international movement of capital. Thus, the fundamental case for trade liberalization and globalization is that it raises the average person's standard of living. ${ }^{8}$

While this benefit applies to the average person, with average income, income is not in reality equally distributed, and increased trade may not benefit everybody. A fundamental result of trade theory, the Stolper-Samuelson (SS) Theorem, identifies winners and losers from trade in terms of the national abundance and scarcity of factors of production, such as labor and capital, from which they derive their incomes. Owners of abundant factors tend to gain more than average from trade, while owners of scarce factors are made unambiguously worse off.. ${ }^{9}$ More general models allow for additional sources of gain from trade and suggest that even owners of scarce factors may gain, in which case SS says only that they gain less than average. But the possibility remains that they actually lose.

So trade theory tells us that, indeed, there may be losers as well as gainers from trade liberalization and globalization. Who are the losers? In countries like the United States, with its abundance of capital, education, and land, the scarce factor is clearly labor. It is not that the United States has a small labor force. Rather, the United States has even more of everything else. In this relative sense, the United States is especially scarce in those workers without a great deal of education, what can simply be called labor. Therefore, international trade theory tells us that the group in the United States most likely to lose from trade liberalization and globalization, or at

\footnotetext{
${ }^{8}$ This conclusion is, strictly speaking, theoretically valid only for countries that are too small to influence world prices with changes in their trade. For large countries, the "optimal tariff" is positive, allowing them to benefit somewhat at the world's expense. While this argument might apply to a country the size of the United States, U.S. levels of protection in sectors where it is highest are well above this "optimal" level, and in any case this argument for protection bears scant resemblance to what opponents of trade liberalization and globalization have in mind.

${ }^{9}$ The formal details are provided in Stolper and Samuelson (1941).
} 
best to gain less than everyone else, is labor. This is hardly a surprise. The opposition to trade liberalization and globalization by organized labor in the United States shows that they are well aware of this. The surprise may be that economists, who tend to favor trade, would agree.

It follows from this also that trade may increase income inequality in advanced countries. Because labor has lower income than those with income from other sources, and because trade lowers the relative wage, it may make the poor relatively poorer. Leaving aside the legitimate question of whether an increased return to some other factors, such as the return to education, may actually increase the opportunity to escape poverty by becoming skilled, it is possible that, in the short run at least, trade liberalization and globalization may increase inequality in rich countries like the United States. In fact, there are empirical studies that suggest that increased trade may account for a portion (although much less than half) of the increased inequality observed in the United States since 1980.

Why, then, is it claimed that there are gains from trade? The reasoning derives from the confidence based on both theory and experience that the winners gain more than the losers lose, enough so that policy could potentially compensate them, leaving everyone better off. In the long run, with some mobility across population groups and with programs to permit the whole population to share in the country's income, most people can expect to be better off with increased trade than without. $^{10}$

SS also applies to developing countries, but in these cases typically the scarce factor is different. Being relatively poor, developing countries can be viewed as the mirror image of the United States, with labor abundant and most other factors scarce, especially capital and education. These belong to the elite, who therefore lose from trade, according to SS. Labor in developing countries can be expected to gain. Since labor in developing countries is far poorer than labor in developed countries, increased trade and globalization can be expected to reduce income

\footnotetext{
${ }^{10}$ Also in the long run, economic well-being depends most on how rapidly countries grow. Here the role of trade is less well understood, but in recent decades countries have grown more rapidly with trade than without.
} 
inequality worldwide, even while it may increase inequality within rich countries.

Are there other gainers and losers from trade, besides the owners of abundant and scarce factors? Yes, and many of them are obvious. Due to trade, some industries expand and others contract. Many people are invested in "industry specific" capital, human and/or physical, in particular industries - skills and equipment that are useful only within an industry. These people gain or lose along with their industries, and some can find the basis for their livelihoods destroyed, a serious cost that public policy can usually only partially acknowledge. For some, these costs can continue for months or even years, as they relocate, retrain, reinvest, and otherwise readjust. Others, especially those later in life, may never recover. International trade theory does not in any way dismiss these costs as unimportant or even as smaller than other gains. Economists therefore usually favor only gradual movement toward freer trade, so that these adjustment costs can be accommodated within the routine ups and downs of markets. ${ }^{11}$

Nonetheless owners of contracting-industry specific factors are a major source of concern in response to increased trade and globalization. These include, for example, American owners and workers in textile and apparel firms, factory workers in developing countries who have been employed during the periods when self-sufficient industrialization was being pursued, and Mexico's small farmers of corn (maize) who now compete with more productive farms in the Midwest United States. These are only a few of the many groups throughout the world who have reason to be concerned about the effects of increased trade and globalization because of their dependence on industry-specific factors.

It is not only whole industries that expand and contract due to trade and globalization. Within an industry, particular firms also win and lose, and firms that have prospered in a protected domestic market may not be the same ones that do well in a globalized economy.

\footnotetext{
${ }^{11}$ In Brown, Deardorff and Stern (1992), for example, the employment reallocation effects of the NAFTA for the United States were estimated and found to be much smaller than the normal turnover within U.S. industries in any one year.
} 
Anticipating in advance the identities of winners and losers may be impossible, but once the process is underway, particular firms will try to speed it up or slow it down, depending on how well they deal with its competitive pressure.

This discussion of gains and losses by particular firms and by specific factors is appropriate primarily to the short run, because in the longer run, people relocate, retrain, and otherwise readjust to changing circumstances. Gains and losses to abundant and scarce factors, in contrast, last longer, continuing even after factors have moved from failing firms and contracting industries into new and expanding ones. However, this is not the end of the story. Over even longer time horizons, the total of a country's factors changes with economic growth. It is reasonable to ask, then, who gains and loses from trade in the very long run, as sizes of countries and their rates of economic growth may change.

An easy answer to who gains and loses from trade in the very long run is: "Not us." Keynes said that "in the long run we are all dead," and he was probably right. Thus, whoever may be the long run gainers and losers from trade liberalization and globalization, they will be subsequent generations, not the present generation. That makes it more difficult to predict how future generations will fare, since we know less about them than we do about the present generation. In a dynamic economy like the United States, the owners of tomorrow's capital, land, and human capital may not be the descendents of those who own these factors today. Therefore, even without economic growth, the best bet for helping future generations is to maximize total income. Trade liberalization and globalization do exactly that. Therefore, there may be a basis for confidence that "everyone” in future generations will benefit from it as trade and globalization continue to grow and spread.

Allowing for economic growth, this conclusion becomes still more likely, although the theoretical basis for it is less certain than the aggregate gains from trade liberalization in the shorter run. Economists do not in fact have a solid theoretical grasp of how trade affects economic growth, perhaps because growth itself is less well understood than the economics of 
static markets. Instead, there exist a variety of models of growth, and even more ideas of how trade may interact with growth. Some predict only that trade permits a country to grow larger than it otherwise would; others suggest that trade lets countries grow faster indefinitely. And there are also models where trade may be bad for growth.

But empirical evidence is much clearer that trade and globalization are good for growth.

Since the end of WWII, most countries that restricted their trade failed to grow significantly, while those that stressed export expansion have done much better. After a few successful countries demonstrated the benefits of trade for growth - especially the "four tigers” of Hong Kong, Singapore, South Korea, and Taiwan - other countries opened their markets and grew faster as well. This process has had setbacks, but few economists today doubt that open markets are beneficial for growth, even if the underlying conceptual connections are not entirely clear.

If so, the case is even stronger that, in the very long run, entire populations gain from increase trade and globalization. Those who are hurt in the short run may lose relative to others. But because they will have a smaller slice of a larger pie, they may well be better off absolutely. That will surely be true if increased trade and globalization permit countries not just to grow to larger size, but to continue growing at faster rates indefinitely. In that case, present and future generations will benefit.

With its expanded role, the WTO will thus affect many groups. But fundamentally it is still, like the GATT, a force for increased trade, and thus for much of globalization. Thus, the preceding discussion about gains and losses to abundant and scarce factors, to industry-specific factors, and to factors unable to move or retrain applies to the WTO. Because the WTO now extends to previously excluded sectors - textiles, apparel, agriculture, and services - those principles will apply especially strongly to them. For example, developedcountry textile workers, who have been protected for decades, have particular reason now to be concerned with the end of the MFA, whereas developing-country textile workers in some 
countries may have corresponding reason to be hopeful. ${ }^{12}$

More generally, however, the WTO has an important institutional role beyond just fostering trade: to constrain countries from using trade policies that will hurt each other and themselves. Without such constraints, two things would guide countries' uses of trade policies. First, large countries would be able to use policies to gain at small countries' expense. Second, weak and misguided governments would be able to use policies to benefit themselves and their “cronies," and domestic political forces would likely lead them to do so. The WTO, with its rules and its DSM for enforcement, helps to prevent both of these unfortunate outcomes.. It protects weak countries from strong countries, and also weak countries from themselves. This is true not only for small countries, but especially for countries that are poor. Thus, even though the WTO was mostly designed by rich countries and even corporations, its greatest beneficiaries may well be in the developing world.

Who loses from the WTO? Again, some of the losers are simply those who lose most from trade, and here the most vulnerable are again the relatively unskilled workers in developed countries. It makes perfect sense that organized labor in developed countries should be skeptical of the benefits from the WTO, for theory predicts that greater trade will indeed hurt their members, at least relatively.

Aside from the foregoing, the rules of the WTO will also hurt those who would wish to break them. If there are large countries that seek to use their economic size at other countries' expense, then they will be frustrated by the WTO. Fortunately, there is little evidence in recent decades that the most powerful countries have sought to do this. More likely losers, therefore, are those who seek to use trade policy for other legitimate purposes but run afoul of the WTO, as in

\footnotetext{
${ }^{12}$ For owners of textile firms in developing countries, it is more complicated. Developed-country firms may move production abroad. Some developing-country firms have prospered, using export licenses under the MFA to make extraordinary profits. But with the elimination of the MFA and increased competition especially from such large, low-cost producers as China and India, many developing-country firms and workers will face difficulties in adjusting.
} 
the shrimp-turtle case. In this case, those who seek to halt environmental degradation naturally wish to use trade policies to pursue their aims, since few other policies work across borders. Yet to do so risks violating the strictures of the WTO. Environmentalists have therefore sometimes been hamstrung by WTO rules, and they believe that they - or the environment - are hurt by the WTO.

It is true that the WTO makes the objectives of environmentalists harder to attain. Policies impose costs, and some are borne by other countries when one country unilaterally uses trade policies for environmental purposes. The WTO gives those costs more weight than if countries could act alone. This means that a lower level of environmental protection will result when these costs are factored in. This is as it should be, however, since global policy decisions should be based on global costs and benefits, including all aspects of all peoples' lives, not just the environment or one country. Environmentalists, whose role is narrower, will indeed make less progress when their interests are balanced against those of others.

Environmentalists might say, "Fine, but the WTO does not just balance other interests against the environment; it rules the environment out of court. All we want is for environmental concerns to be heard in the WTO.” In fact, the WTO does include several environmental clauses, so even here the question is one of balance. How much role should environmental concerns play in justifying trade policies? Arguably, the current system has not done badly. The problem with using trade policies for environmental and other purposes is that they too easily push the cost onto others. The WTO has forced their advocates to find fairer ways to achieve those purposes. For example, the shrimp-turtle dispute led, more quietly, to shrimp fishermen being equipped with TEDs at developed country expense. It could be said that this was the right solution all along.

There are other issues, besides the environment, whose advocates wish to use trade policies, including human rights and labor standards. For both, the United States especially has used trade policies in the past to deny trade preferences for some developing country trading partners that are allegedly pursuing abusive labor policies. Some U.S. groups view the WTO as 
an enemy of human rights and labor standards. This conclusion may not be justified, however, but, as with the environment, as the WTO interferes with policies that would otherwise be available to pursue these ends, the ends themselves will not be attained as fully as some groups desire.

In the case of human rights, the WTO does permit some use of trade policies, such as the economic sanctions that were used against Rhodesia in 1965 and against South Africa in 1985. Formally, these were permitted under GATT Article XXI, based on actions under the United Nations Charter for purposes of peace and security. ${ }^{13}$ The WTO does not permit unilateral sanctions for human rights, however.

In the case of labor standards and labor rights, the issue is more complex, partly because it is so difficult to separate the moral from the economic, and partly because of different views of what labor standards mean economically. ${ }^{14}$ Some labor standards, such as the prohibition of slave labor and exploitative child labor, are clearly moral issues. Others, such as a minimum wage, are economic. And still others, such as working conditions and child labor with the approval of caring parents, are somewhere in between. It is hard to say where to draw the line and who should draw it. ${ }^{15}$

Economically, most labor standards affect the cost of labor, even when not explicitly about wages. But their effects depend on how one believes that wages are determined. From the perspective of competitive markets, which guides most economists on this issue, labor standards are mostly about the remuneration of labor in poor versus rich countries, and higher labor standards in the former primarily benefit the latter, putting developing country workers out of work. Another view, however, is that all labor remuneration is at the expense of capital, so that higher labor standards merely reduce profits. This second view makes most sense if employers

\footnotetext{
13 See Jackson and Davey (1986, p. 917).

${ }^{14}$ The line between human rights and labor standards is not always clear. The right to organize and a safe workplace are both on most lists of labor standards, but they might also be regarded as human rights.

${ }^{15}$ For more on labor standards, see Brown and Stern (2007).
} 
have market power, something that trade liberalization and globalization are in fact likely to undermine. But not everyone believes market economics, and there are plenty of subscribers to this second view among opponents of the WTO. In their view, by excluding labor standards as a basis for trade policy, the WTO helps capitalists and hurts workers, everywhere. But modern economics suggests that only developed-country workers may be hurt, while the true beneficiaries of the WTO are the developing-country workers for whom labor standards are ostensibly meant to help.

The latter view is voiced prominently by most economists and by most leaders of developing countries. They perceive labor standards, when enforced by trade sanctions, as thinly disguised protection for developed-country labor. The WTO thus excludes labor standards as part of its broader role of protecting the weak from the strong. Thus, at the 1996 GATT Ministerial Meeting in Singapore, it was decided that issues of labor standards should be handled in the International Labor Organization, which was established in the 1920s with the express purpose of improving labor rights and working conditions but without resort to the use of trade sanctions to punish alleged violations of worker rights.

\section{Other Objections to the WTO}

Even among those who conclude that it is appropriate for the WTO to limit its jurisdiction on issues of the environment and labor standards, however, the WTO does nonetheless have some limitations. One is its lack of transparency. The proceedings of the DSM panels are generally closed and make only limited use of information from non-government sources. Some observers regard this mechanism as non-democratic, and they fear its capture by corporations with financial stakes in the outcome. They would like interested NGOs to be able to provide more input to the process, and perhaps to have the panelists themselves selected by a process that NGOs could influence.

The complaint about non-democratic procedures is ironic, however, since the WTO 
works by consensus among mostly democratic governments, whereas NGOs are by definition self-appointed special interests. More important, however, is a concern from developing countries, that opening the DSM to greater public scrutiny and influence would cause its capture by precisely these special interests, at developing-country expense. Nonetheless, even defenders of the WTO recognize that the DSM's procedures may be counterproductive. It has thus become increasingly common in DSM cases to permit NGOs and others to file "friend of the court briefs.” Some observers also argue that a more permanent body should replace the panels themselves, instead of being assembled case-by-case. If so, then greater public input to selection of that body might be natural.

A further concern has long been that a few rich countries dominate the WTO, developing countries having little role. This is true in spite of - or even because of - its formal reliance on consensus. With 150 member countries, however, consensus is not practical, and therefore a smaller group has typically sought agreement among themselves, thereafter coming to the larger group for approval. This smaller group, sometimes referred to as the "green room group" after the room in which they have sometimes met at WTO headquarters in Geneva, has been assembled on an ad hoc basis by the Director General and has included both developed and developing countries based on their interest in the issues being addressed. However, many developing countries - especially smaller ones - have been excluded and not formally represented, not by design because there was no design, but by default. Exactly how to change this aspect of WTO governance is not clear, but it requires careful consideration.

As already noted, a common objection to the WTO is that it overrules domestic laws. This is true, for that is its purpose. The GATT was a treaty among countries to prevent them from using certain laws and policies that would adversely affect each other. The WTO continues that purpose. However, while the original GATT dealt only with tariffs, over time the GATT/WTO has expanded to many other policies whose main purposes are not international. Critics object that the WTO undermines domestic policies, not just tariffs. Presumably, countries 
might well want to reconsider membership if they find WTO rules too onerous, but to date no countries have found it in their interest to leave the organization. ${ }^{16}$

A final concern of many WTO critics is that it is dominated by large corporations. This is true and probably inevitable, since it is large corporations that do most trade. Corporations have both the incentive and the resources to influence policies, and they do, both within countries and internationally. This means that the WTO has elements that would not be there without corporate lobbying, and some of these elements are undesirable. For example, antidumping statutes are economically nonsensical and pernicious, and yet the GATT has always permitted them, for the obvious reason that many corporations want them. More recently, in response to corporate lobbying the Uruguay Round added intellectual property rights to the WTO, in spite of strong resistance from developing countries that ultimately was overcome by the promise of market opening in textiles and apparel.

The WTO, then, is not a perfect organization. It could be improved, but many of its flaws will inevitably remain, because they are there in response to political realities. Overall, it seems clear that the WTO serves an extremely useful purpose, and that it serves it surprisingly well.

One indication that the WTO is not too far off the mark comes from its opponents. Although they share unhappiness with the WTO, some say that it does too much, others that it does too little. Environmentalists usually complain that it does too much, ruling against national

\footnotetext{
${ }^{16}$ A troubling feature of the WTO for some countries is imports may not be restricted based upon the process by which they were produced. The WTO permits countries to exclude goods deemed harmful to health or the environment, for example, but only based on observable characteristics of the products themselves. In practice, countries often want to exclude imports that were produced by a process that has harmed the environment, has violated labor standards or human rights, has adverse health consequences for consumers, or may be otherwise undesirable. These are often legitimate concerns, and if the process could be inferred from a product characteristic at the border, the WTO might permit their exclusion. However, the problem with exclusion based on process is that there is no way to observe the process at the border when goods are being imported. Countries must therefore in practice exclude imports based on where they were produced, excluding all imports from any country that does not effectively ban the offending process. Permitting restrictions based on process runs the risk of imposing particular production techniques on countries, and thus of undermining their comparative advantage. For these reasons, the WTO has maintained its position that process-based import restrictions are unacceptable.
} 
efforts to improve the environment, and they want it weakened or destroyed so that national policies can proceed unhindered. Labor activists, on the other hand, complain that it does too little, not enforcing labor standards around the world. They want the WTO to take on more issues, and interfere more with national policies.

\section{Issues of National Sovereignty and the Boundaries of the WTO ${ }^{17}$}

As already noted, world trade liberalization made great strides after WWII on the basis of the two major pillars of multilateralism: reciprocity and non-discrimination (MFN). Until the Uruguay Round (1986-93), the periodic GATT negotiations focused on the reduction of external trade barriers to make gains in reciprocal and non-discriminatory market access. During and since the UR, these underpinnings of the multilateral system have lost their primacy. In the course of the UR, there was an extension of trade rules, directed most notably toward the liberalization of domestic markets for services and investment and toward the protection of IPRs. Following the conclusion of the UR, efforts were made to include the so-called Singapore issues of competition, investment, government procurement, and trade facilitation on the agenda of the WTO Doha Development Agenda negotiations. Attempts have also been made to incorporate labor and environmental standards into the WTO. All of these developments reflect the idea, not simply of promoting trade liberalization among separate national markets, but of furthering global market integration through the convergence of national market regulations. In some degree, the breakaway from non-discrimination through the proliferation of free trade agreements (FTAs) in the past decade only accentuates the movement away from trade liberalization based on reciprocal gains in market access.

It can be argued that the existing and proposed extensions of the WTO into domestic rule making may be misguided. That is, the central role of the WTO should be viewed as facilitating commercial relations among its member nations. It is by no means clear therefore that the WTO

\footnotetext{
${ }^{17}$ This section has been adapted from Brown and Stern (2006).
} 
should be an instrument to shape national markets and institutions so that they will conform to some idealized model of how a global economic system should work. The point is that there are boundaries to the extent to which WTO disciplines can, or should, superimpose themselves on commercial conduct in national markets.

\section{The Boundaries to the WTO Regime}

To clarify the scope of the WTO, Table 2 provides a categorization of the various actual or proposed disciplines of the WTO regime. These include: (1) core disciplines; (2) disciplines that may require modification to take legitimate national interests into account; (3) preferential trading arrangements that do not inhibit global trade; (4) national regulations involving health, safety, and consumer protection; and (5) national regulations that lie wholly beyond WTO boundaries. While not included explicitly, allowance needs to be made under the foregoing disciplines/boundaries for provision of Special and Differential treatment to low income or least developed countries.

In considering the WTO boundaries, there are two conditions to bear in mind: (1) the positive economic nationalism that legitimately motivates most governments to pursue policies that are sincerely believed will improve the material well-being of their populations and sustain their social cohesion; and (2) the institutions surrounding national markets that are embedded in social mores and the particular structure of business organization. When WTO rules and procedures are pushed beyond the boundaries set by these conditions, they may sour trade relations and erode the general consent to the core disciplines on which the effectiveness of the WTO rests. 
To expand further on the application of WTO boundaries, we now elaborate on the interpretation of these conditions, ${ }^{18}$ addressing subsequently how the WTO "playing field" may be best delineated and the role of the WTO in dealing with preferential trading arrangements.

\section{Economic Nationalism}

Economic nationalism is widely used as a pejorative term. It manifests itself frequently in international economic relations and policies and is usually rightly denounced by trade specialists as a regression into mercantilism. There is a long history of beggar-thy-neighbor policies in international economic affairs, and the guardians of economic rationality are justly wary of nationalist rhetoric. But that should not blind them to the reality that nationalist sentiment is a powerful force that also has positive economic consequences. The great revolution in rising expectations, which first began within some Western countries in the 18th and 19th centuries, has since swept around the world; and politically vocal people everywhere expect that their own national governments will take measures to improve their material well being. Though the great majority of countries now have capitalist systems, beliefs about how governments could best accomplish this purpose vary widely; and they have changed within countries over time. But what has remained ever present is the responsibility that peoples place on their governments - as the highest political authority in their societies - to seek gains in national well being. As illustrated below, such economic nationalism sets limits that have to be respected in multilateral rule making.

\section{Domestic Subsidies and Industrial Policies}

Among today's established industrial countries, governments broadly see themselves as fulfilling their responsibility if they are able to maintain technological leadership - at least in some sectors - or, at worst, not fall behind other countries in the endless race toward economic betterment.

\footnotetext{
${ }^{18}$ Issues of delimiting the WTO boundaries are also addressed in Hoekman $(2002,2004,2005)$ and Sutherland et al. (2004, esp. 61-72).
} 
Accepting that private enterprises should make most economic decisions in response to market prices, they see their responsibility largely as the support of education, provision of infrastructure, and promotion of general scientific and technological research and development. Such economic nationalism has been reflected in the WTO mainly through its rules on subsidies. While government subsidies to individual firms or industries are often seen as contraventions of "fair" trade because they may distort market prices, subsidies of general research and development are not so viewed. The lines between specific and general subsidies are, however, not always clearcut. For example, in very large-scale industries like the aircraft industry, EU subsidization of the Airbus and U.S. defense procurement favoring Boeing have been an ongoing source of bilateral friction. Yet, until recently, the EU and U.S. policies have broadly remained in place, although they are now under challenge in the WTO dispute settlement procedure, albeit with an uncertain outcome. Other manifestations of economic nationalism stem from cross-border mergers and acquisitions that may threaten the independence of national corporations regarded as "national champions.” But they have so far not been constrained in this area by the WTO since it has no agreement on competition policy.

Most developing country governments have been no less powerfully motivated by economic nationalism. In the earlier post-WWII years, indeed, the sense of national pride enhanced by new won independence - occasioned widespread nationalization of foreign enterprises and stressed the development of nationally-owned enterprises. While most governments have since shed their hostility toward foreign investment, they have not lost their determination to foster the expansion of a rising indigenous industrial sector. Countries that have made substantial progress in industrialization have generally made extensive use of policies intended to provide inducements to, and financial and technical support for, national firms to encourage expansion of production and introduction of new products and processes. By such means, they have sought to benefit from learning spillovers, and to overcome coordination failures that might otherwise impede their economic growth. However, such policies - pursued 
on the nationalist grounds that they promote indigenous development and evidently effective in the circumstances - are perhaps not consistent with the rules of the GATT/WTO as these rules now stand. But it is noteworthy that national policies have for the most part been considered to lie within the purview of governments and have not been challenged in the GATT/WTO. Efforts to restrict domestic subsidies that constrain industrial policies should therefore be carefully circumscribed in the WTO.

\section{TRIMS and TRIPS}

In the UR negotiations, agreements on "trade related" investment measures (TRIMS) and IPR (TRIPS) protection were incorporated into the WTO.. These are clear examples of the extension of international rule making into areas of domestic policy.

The TRIMS Agreement fell short of what its sponsors - mainly the United States sought. They had hoped for an agreement on foreign investment that, when taken together with the GATS (which accorded foreign investors the right of establishment in service industries), would succeed in gaining less restricted access to the markets of other countries for their corporate investors. They also hoped that, once their investors had been granted access, such foreign investment would enjoy full national treatment. These aims were not realized. However, developing countries had to accept some restrictions on their freedom to apply conditions on FDI. They were no longer permitted to impose local content requirements on foreign enterprises to mandate their meeting particular levels of local procurement, or stipulate that foreign enterprises meet trade-balancing requirements. Underlying TRIMS is an evident conflict between the legitimate economic nationalism of developing countries in pursuing measures intended to advance their own development and the commercial interests of multinational corporations.

The TRIPS Agreement addresses long-standing issues of foreign piracy and counterfeiting of patents, copyrights and trademarks that have always been of concern to the owners of these IPRs. In the earlier stages of their own industrialization, the now industrialized 
countries were generally neglectful of foreign-owned IPRs. Freewheeling imitation and reverse engineering of foreign products and processes were principal means of gaining new technology (Chang, 2002). However, as these countries themselves began to generate technological innovations, they acquired an interest in the reciprocal recognition of IPRs. What TRIPS accomplished was an extension of such mutual recognition to all WTO members. For a great many developing countries, however, the element of reciprocity has been largely absent from the agreement, since they have had few IPRs for which they might seek recognition abroad. On the other hand, the agreement has restricted their freedom to copy and apply new technologies at will. Further, utilization of new technologies patented elsewhere will require payment of royalties or fees, implying a transfer of financial resources from poor to rich countries.

Defenders of the new discipline point to the potentially beneficial development effects. Their argument is that, as the rights of patent holders are now more secure, corporations may be more willing to set up production in countries where they formerly feared that their patented processes would be surreptitiously stolen and copied. But against this is the check that the discipline imposes on the unrestrained transfer of technology. WTO members have, at least, recognized this in the special provisions agreed to in regard to pharmaceutical patents and the treatment of HIV/AIDS, malaria and tuberculosis. ${ }^{19}$

It can be argued that the TRIMS and TRIPS Agreements may well lie outside the appropriate boundaries for many WTO developing country members. In my judgment, the broader investment measures that were part of the Singapore agenda and that were shelved following the September 2003 WTO Cancun Ministerial should be permanently shelved. Furthermore, the transition period for TRIPS conformance should be made open ended for developing countries until such time as they themselves will benefit - both internally and through

\footnotetext{
${ }^{19}$ A well informed and balanced assessment of IPRs and development is provided in the report of an international group of experts appointed by the U.K. government. (Commission on Intellectual Property Rights, 2002).
} 
the reciprocal recognition of rights - by implementing the domestic laws and institutions needed to carry out the enforcement procedures of the Agreement.

\section{Government Procurement}

In the course of the Tokyo Round in the late 1970s, a plurilateral agreement on government procurement was negotiated to become effective in 1981, with a number of industrial country signatories. There are presently 28 signatory governments. The agreement was designed to make the procedures and practices of government procurement more transparent and nondiscriminatory as between domestic and foreign suppliers. The emphasis is on tendering practices and covers both designated national and local government entities, with specified threshold values for the contracts involved. While the number of signatory countries has expanded, it is noteworthy that comparatively few developing countries have become signatories. The reason apparently is that the procurement agreement is viewed as being overly intrusive in challenging the rights of governments to maintain control over the award of contracts and programs for public procurement.

It may be the case that existing procurement policies in many countries are inefficient, costly, and subject to rent seeking, so that measures to reform these policies may therefore be in a country's national interest. But it is not clear why such reform should be carried out under WTO auspices, especially since a substantial amount of public procurement may stem from pursuit of a variety of social and political objectives and programs that are at the foundations of domestic government policies and may only tangentially be trade related. It is not surprising therefore that many developing countries were opposed to inclusion of government procurement, one of the Singapore issues, as part of the Doha Development Agenda negotiations. As in the case of investment policies, government procurement was shelved following the Cancun Ministerial Meeting.. 


\section{Markets and Institutions}

It is obvious that national markets function within a framework of laws, regulations, and more informal, but well embedded, practices; and that the framework differs widely among countries. Some obvious forces that account for the differences are the social mores of each country, its political institutions, and the particular forms of organization of its firms and industries as its capitalist system has evolved. These have never prevented transactions across national frontiers. So long as traders share some core similarities in modes of commercial conduct, they have been able to trade advantageously with each other. It has been enough that they share respect for private property rights and contractual arrangements, and that they accept some judicial procedure for resolving disputes. But in a world of nation states, traders have also found that the differences in laws, institutions and social practices may impede their access to foreign markets. This has driven the search in the GATT/WTO for common rules that would ensure greater similarity in competitive conditions. Firms in the leading economic powers have deemed dissimilarities from their own national conditions to give rise to "unfair" competition and have called for a "level playing field.” This has been powerfully supported, at the intellectual level, by an idealized neo-classical model of markets that presupposes universal institutional conditions associated historically with the development of capitalism in the United States or Great Britain.

There are, however, limits on the extent to which nations can be expected to conform to multilaterally established rules that may challenge their own social mores or forms of business organization. To be effectively applied at home, rules have to be compatible with the prevailing beliefs and practices within which the domestic market functions. Rules that are in conflict will not be accepted or, if formally accepted, will not be enforced or will be enforced only weakly. Certainly, some distinction has to be drawn here between laws, regulations and practices that are deeply embedded and those that lie more on the surface or merely benefit rent seekers. Cumbersome and outmoded customs procedures, for instance, may not reflect any deeply held beliefs, and their reform may be impeded only by bureaucratic inertia. There is no objective test 
by which to determine where the line lies, but there are some reforms proposed as appropriate for the WTO that may exceed the appropriate boundaries.

\section{Competition Policy}

Competition policy is a case in point in which the diversity in forms of business organization among countries limits the possibility or desirability of common rules. There are many variants of capitalism as it has evolved in the unique political, social, and economic circumstances of each country. Perhaps two of the most striking circumstantial differences are the relations between the state and private enterprises and the interrelations among firms themselves. In most English speaking industrial countries, for example, the relationships between private enterprises and government have historically been more adversarial and arms length in comparison with the more cooperative relations in many other countries. Likewise, there are many differences in the competitive or cooperative relations among firms that are socially regarded as acceptable. These give rise to differences in market practices that foreign producers may see as impediments to trade.

An example is the Structural Impediments Initiative that was prominent in U.S.-Japan relations in the 1980s and 1990s, and that involved U.S. pressure on Japan to change longstanding business practices and institutions that allegedly constrained access of U.S. exports and FDI in the Japanese market. The WTO was involved in two prominent cases dealing with U.S. access to Japan's domestic market in automobiles and film. The United States decided to drop the automobiles complaint and was on the losing side of the WTO dispute settlement decision to deny the Kodak film complaint. ${ }^{20}$ In retrospect, the U.S. actions may have been ill advised to begin with. It also appears that the Japanese Government instituted measures on its own in recognition of the national need for institutional and policy reform in a number of sectors.

Arguments similar to the foregoing can be applied to developing countries. It can be

\footnotetext{
${ }^{20}$ For an analysis of the Kodak-Fuji film dispute between the United States and Japan, see Devereaux, Lawrence, and Watkins (2006, Vol. 2, pp. 143-191).
} 
argued accordingly that competition policy may lie outside the appropriate boundaries of the WTO regime. This was another of the Singapore issues that was shelved following the September 2003 WTO Cancun Ministerial Meeting.

\section{Labor Standards}

Labor standards are another case in point. As noted in the earlier discussion, there have been strong political pressures from organized labor and social activists to seek the incorporation of labor standards in the WTO. But it may suffice to note that the case for inclusion of labor standards in the WTO rules, on grounds of economic welfare, is widely regarded as very weak, both in logic and empirically. The best contribution that the WTO can make to raising labor standards is accordingly to facilitate the expansion of world trade since, almost everywhere, as economic growth has taken place and incomes have risen, working conditions have sooner or later improved.

Nonetheless, the proponents favoring inclusion of labor standards in trade agreements have been powerfully reinforced by their claim to the high moral ground in arguing that, whatever the economic consequences, it is morally wrong to condone poor labor standards in other countries. No one would contest the right of individuals or groups to advocate the norms of their society or to call for economic sanctions when the most egregious violations of human rights are being committed. In the present context, however, the issue is whether industrial nations, by virtue of their power, should, as a condition of trade, insist that other countries respect particular labor standards that they themselves value and that are interwoven with the levels of individual and social well-being, which thanks to their long history of economic growth, they now enjoy.

Many developing countries see this demand as presumptuous and politically self-serving, as the governments of industrial countries appear to be placating domestic groups that either represent sectional interests or are not well informed. But there is a more pragmatic reason for rejection of this position, which is that it is very likely to be ineffective. The transplant of social 
norms from one society to another is exceedingly difficult to accomplish. Everywhere, changes in domestic regulations embodying new norms of behavior take place in response to demands from coalitions of politically influential groups within the country. External leverage applied through trade threats may possibly tilt the balance in favor of reform, but by itself will rarely bring about any lasting change in prevailing social beliefs and practices. What the inclusion of rules about labor standards in the WTO would most likely accomplish is its entrapment in disputes about policies that countries regard as wholly domestic affairs.

\section{Environmental Standards}

The arguments just made concerning labor standards may apply to domestic environmental standards, which will depend on prevailing social beliefs and practices and differences in per capita incomes between nations. Just as with labor standards, the determination of environmental standards should therefore lie outside the boundaries of the WTO.

\section{Health and Safety Standards and Consumer Protection}

Another problematic policy area for the WTO is the range of measures that governments may design and implement with regard to health and safety standards and consumer protection. In this connection, EU policies regarding imports of hormone-treated beef and products containing genetically modified organisms (GMOs) provide an apt illustration of the limits of WTO policies. $^{21}$ The issues here concern the rights of nations to establish their own national health and safety standards, including the restriction of imports deemed to contravene national standards. Such standards can be and have been used for protectionist purposes, and there may not always be a firm scientific basis to warrant certain standards. But so long as governments believe it is in the national interest to protect public health, the right to do so should be respected. Depending on how scientific evidence evolves, governments may then decide over time to moderate their

\footnotetext{
${ }^{21}$ The U.S.-EU WTO disputes hormone-treated beef and GMOs are analyzed in Devereaux, Lawrence, and Watkins (2006, Vol. 2, pp. 31-96 and pp. 283-344).
} 
restrictions, as, for example, the EU has been doing recently with GMOs. This suggests accordingly that the rules and decisions of the WTO should not be rigidly applied in cases in which public health is at issue, and there is lacking a consensus regarding the available scientific evidence for the production and processing of the products involved.

\section{The Playing Field}

So, if we accept the limits described above, how is the WTO's playing field to be defined? The role of the WTO is to provide a framework in which governments can negotiate and monitor the reduction of impediments to trade that serve no larger purpose than the protection of sectional interests within individual countries. Such impediments cannot be legitimately defended on the kinds of grounds discussed above. They serve only to lower economic efficiency within the countries in which they are practiced and deprive producers in other countries of wider market access. The world abounds in these impediments, and their gradual reduction is the raison d'etre of the WTO. Drawing the line between these impediments and those that have larger purposes is the task of the WTO rules.

As already mentioned, agricultural impediments illustrate this point. Even if, for example, as the EU, Japan, and other nations assert, the subsidization of agriculture has broad social as well as economic aims, it is an inefficient way of accomplishing the social purposes as well as meeting economic needs. The economic case against agricultural subsidization as serving sectional interests and lowering national efficiency appears to be well founded. A similar case can be made against the resort to antidumping measures that are the policy of choice by protectionist interests in developed countries and have become increasingly widespread in developing countries.

Sectional interests are, of course, everywhere and governments are rarely independent of them. For individual governments, trade negotiations based on reciprocity have the advantage that they pit export interests against sectional protectionist interests. Negotiations force 
governments that want wider market access abroad to liberalize at home. It is a great benefit of the WTO that, in bringing countries together around the negotiating table, pressures are openly and internationally placed on protectionist domestic interests.

Many issues are not clear-cut and rules can never be drawn that are always unambiguous or that foresee changing circumstances. A mechanism for dispute settlement is consequently essential, but it should not be called upon to adjudicate on policy issues. Its business is the interpretation of existing rules, not the formation of policy. So, in the rules-making process, it is important that new rules should enjoy widespread consent.

\section{Free Trade Agreements}

We need finally to consider how the WTO boundaries should be defined with respect to FTAs. FTAs often manifest the "real politik" that motivates nation states in pursuing national selfinterest in their external relations. Many FTAs that have been negotiated involve neighboring countries that already trade extensively with each other, so that there has been comparatively little trade diversion, except perhaps in some labor-intensive sectors such as textiles and clothing.

Except for U.S. FTAs, most other FTAs are confined mainly to the bilateral removal of tariffs and quotas. U.S. FTAs are more invasive in seeking to extend the integration of markets to cover many non-trade issues and to impose conformity with U.S. institutions and policies. Nonetheless, FTA members are still bound by WTO rules, which may help to explain why we have not witnessed the formation of major trading blocs as some analysts had postulated might occur. It may be the case furthermore that FTAs are becoming generalized as both large and small countries are seeking to expand their arrangements to help offset preferences provided in previously negotiated FTAS. But there are some large countries like Brazil, China, and India that are latecomers to the FTA process and are not likely to become partners in FTAs with the major industrialized countries. It may well turn out then that these large developing countries will become bulwark supporters of the WTO multilateral system. 
There is, however, some role for the WTO to play in encouraging the greater openness of existing FTAs by expanding FTA membership, thereby moving the trading system closer to multilateralism. It might thus become possible to dispense with the rules of origin and remove the distortions that have been created by the many overlapping FTAs that now exist. Continuing pursuit of multilateral trade negotiations will also serve to erode preferential trade margins incorporated into FTAs and offer countries greater benefits than they may obtain from FTAs.

\section{Conclusion}

In this paper, we have reviewed the development of the present-day global trading system. We have noted that the success of the GATT system prior to the Uruguay Round (UR) was based on the twin pillars of reciprocity and non-discrimination. But during and since the conclusion of the UR, there has been a pronounced shift toward the pursuit of conformity in domestic regulatory policies and institutions covering a variety of institutions, business practices, and social mores. It can be argued this expansion of the boundaries of the WTO into domestic areas may be misguided.

Countries cooperate with each other through the WTO in order to benefit mutually from international specialization. To this end, they negotiate reductions in trade barriers and agree on supporting rules of conduct to verify compliance. Businesses, after all, have a legitimate concern that reductions negotiated on their behalf should not be effectively annulled by domestic measures later taken by trading partners. But this does not mean that the WTO should be taken as a vehicle for the dissemination of values or economic beliefs that are not widely shared. The criterion of success for WTO rules is that they should be widely, and willingly, accepted as necessary to promote mutually advantageous trade relations. If this is not so, the cooperation on which the system rests is vitiated. ${ }^{22}$

\footnotetext{
${ }^{22}$ For further elaboration on this point, see Brown and Stern (2005).
} 
To be sure, there are strong differences in views about where the WTO boundaries should lie. But too much energy can be poured unproductively into debate about the boundaries. Within the WTO boundaries, there is great scope for further multilateral action to lower trade barriers and widen markets. There are many trade barriers that do not bear close scrutiny as rational measures either from a national or an international viewpoint. They can neither be defended as measures integral to national growth or development policies nor embedded in social values or in the long-standing structure of business organization. Unbiased analysis would reveal that they are no more than the abuse of governmental powers to protect special interests.

But where does the drive to confront these interests and remove the protectionist barriers come from? In recent decades in the developing world, it has come sometimes from governments committed to a radical shift in economic policies that have privatized and deregulated at home and liberalized external trade. More generally, over time, in both industrial and developing countries, it has come incrementally through pressures from their own export interests to negotiate for improvements in market access abroad. Reciprocity has demanded, however, that countries face up to at least some of their own protectionist interests and remove barriers.

Thus, reciprocity in the reduction of barriers to trade in goods and services remains the key to further trade liberalization. There are many other actions that the WTO can, and does, take to facilitate trade and smooth trade relations. But its task should not be the integration of national markets into one grand global market. By the same token, the rise of FTAs has been eroding the principle of non-discrimination. While market forces and particularly the resistance of some of the major emerging economies may gradually result in restoration of respect for nondiscrimination, the WTO could play a key role in convincing the countries that are parties to FTAs to change the nature and structure of these arrangements to move the trading system closer to the multilateral ideal and to continue pursuit of multilateral trade negotiations that will benefit countries even though preferential margins will be eroded. 


\section{References}

Brown, Andrew G. and Robert M. Stern. 2006. "Global Market Integration and National Sovereignty,” The World Economy 29, No. 3:257-279.

Brown, Andrew G. and Robert M. Stern. 2007. "Concepts of Fairness in the Global Trading System,” Pacific Economic Review, forthcoming.

Brown, Drusilla K., Alan V. Deardorff, and Robert M. Stern 1992 "A U.S.-Mexico-Canada Free Trade Agreement: Sectoral Employment Effects and Regional/Occupational Employment Realignments in the United States," in National Commission for Employment Policy, The Employment Effects of the North American Free Trade Agreement: Recommendations and Background Studies, Special Report, October.

Brown, Drusilla K. and Robert M. Stern (eds.). 2007. The WTO and Labor and Employment. Williston, VT: Edward Elgar Publishing Inc.

Carroll, L. 1946, Alice's Adventures in Wonderland (London: Penguin Group).

Chang, H.J. 2002, Kicking Away the Ladder: Development Strategy in Historical Perspective (London, Anthem Press).

Crafts, Nicholas 2000 "Globalization and Growth in the Twentieth Century," International Monetary Fund, Research Department, Working Paper WP/00/44, March.

Deardorff, Alan V. 1990 "Should Patent Protection Be Extended to All Developing Countries," The World Economy 13, (December), pp. 497-507.

Deardorff, Alan V. and Robert M. Stern. 2003. "What the Public Needs to Know about Globalization and the WTO,” Review of International Economics, 2002.

Devereaux, Charan, Robert Z. Lawrence, and Michael D. Watkins. 2006. Case Studies in US Trade Negotiations, Vol. 2: Resolving Disputes. Washington, D.C.: Institute for International Economics.

Hinde, W. 1987, Richard Cobden: A Victorian Outsider (New Haven and London: Yale University Press).

Hoekman, Bernard. 2002. "Strengthening the global trade architecture for development: the post Doha agenda,” World Trade Review1:23-45.

Hoekman, Bernard. 2004. "Overcoming Discrimination Against Developing Countries: Access, Rules and Differential Treatment," Centre for Economic Policy Research, Discussion Paper No. 2694 (October).

Hoekman, Bernard. 2005. "Operationalizing the Concept of Policy Space in the WTO: Beyond Special and Differential Treatment,” Journal of International Economic Law 8:405-24.

Jackson, John H. and William J. Davey 1986 Legal Problems of International Economic Relations 2nd Edition, St. Paul, Minn.: West Publishing Co.

Keohane, R.O. 1984, After Hegemony: Cooperation and Discord in the World Political Economy (Princeton, New Jersey: Princeton University Press).

Pigman, G.A. 2002. Hegemony Theory, Unilateral Trade Liberalization mad the 1996 US Farm Bill in P.K. O'Brien and A. Clesse (eds.), Two Hegemonies: Britain 1846-1914 and the United States 1941-2001 (Aldershot, England and Burlington, VT: Ashgate Publishing Limited). 
Srinivasan, T.N. 2005. "Nondiscrimination in GATT/WTO: was there anything to begin with and is there anything left? World Trade Review 2:69-95.

Stolper, Wolfgang and Paul A. Samuelson 1941 "Protection and Real Wages," Review of Economic Studies 9:58-73..

Sutherland, Peter (Chairman) et al. 2004. The Future of the WTO: Addressing institutional challenges in the new millennium. Geneva: WTO.

Whalley, John. 2005. “Globalization and Values,” CESifo Working Paper Series No. 1441 (April).

Whitman, Marina v.N., 2004. "From Trade Liberalization to Economic Integration: The Clash between Private and Public Goods," in Jacob Ryten (ed.), The Sterling Public Servant: A Global Tribute to Sylvia Ostry, Montreal \& Kingston: McGill-Queen's University Press. 


\section{Discussion Questions}

1. Define reciprocity and non-discrimination (Most-Favored-Nation/MFN). What are the historical origins of these trade-policy instruments? What happened to international trading relations in the period between WWI and WWII? What was "conditional” MFN as used by the United States and why was this policy changed?

2. What is globalization? How it is measured, and how has it changed in the past century or more?

3. Whom does trade liberalization and globalization help or hurt? What are the static effects of trade? Dynamic effects? What are the effects of international capital flows? Other effects of trade liberalization and globalization?

4. What was the purpose of the General Agreement on Tariffs and Trade (GATT) after WWII? How well did the GATT achieve its objectives? How did the WTO come to be formed, what are its main activities, and how does it differ from the GATT? Whom does the WTO help or hurt? What has caused the broadening of the agenda of multilateral trade negotiations? How have developing countries been treated under the GATT and WTO? Why has reciprocity lost much of its clarity?

5. What is the meaning of a "level playing field" in international trade relations? What is the "cosmopolitan" view of the global economy? What is the "national sovereignty" view?

6. When and why did U.S. policy shift away from multilateralism towards regional and bilateral trade agreements? The EC and Japan? Emerging market economies and developing economies? Why haven't the major industrial countries - United States, EU, and Japan - formed competing preferential trading blocs? Are free trade agreements (FTAs) a stumbling block or a positive movement towards global trade liberalization? How may FTAs constrain developing countries?

7. Are the existing and proposed extensions of the WTO into domestic rule making misguided? What are the boundaries or disciplines that comprise the WTO regime? What is the significance of economic nationalism and institutions embedded in social mores and the structure of business organization? How do the following issues fit within the WTO boundaries: domestic subsidies and industrial policies; TRIMS and TRIPS; government procurement; competition policy; labor standards; environmental standards; and health and safety standards and consumer protection?

8. How should the WTO "playing field” be defined? Should agricultural protection, antidumping, and other protectionist actions be dealt with in the WTO negotiations and rule making? What is the role of WTO dispute settlement? How should the proliferation of FTAs be addressed?

9. How successful has trade liberalization been in the past 50 years in the GATT/WTO system? What are the future prospects for reciprocity and non-discrimination as the keys to further trade liberalization? 
Table 1

Rounds of GATT/WTO Multilateral Trade Negotiations

\begin{tabular}{|c|c|l|l|c|}
\hline No. & Years & Name & \multicolumn{1}{|c|}{ Accomplishments } & Countries \\
\hline 1 & 1947 & Geneva & Reduced Tariffs & 23 \\
\hline 2 & 1949 & Annecy & Reduced Tariffs & 13 \\
\hline 3 & 1951 & Torquay & Reduced Tariffs & 26 \\
\hline 4 & 1956 & Geneva & Reduced Tariffs & 26 \\
\hline 5 & $1960-61$ & Dillon & Reduced Tariffs & 62 \\
\hline 6 & $1964-67$ & Kennedy & Tariffs and Anti-dumping & 102 \\
\hline 7 & $1973-79$ & Tokyo & Tariffs and NTBs, Framework Agreements & 123 \\
\hline 8 & $1986-94$ & Uruguay & $\begin{array}{l}\text { Tariffs, NTBs, Rules, Services, Intellectual Property, } \\
\text { Textiles, Agriculture, Dispute Settlement, Created } \\
\text { WTO }\end{array}$ & 150 \\
\hline 9 & $\begin{array}{c}2001 \text { to } \\
\text { date }\end{array}$ & $\begin{array}{l}\text { Doha cover reduction/removal of: agricultural tariffs, } \\
\text { export subsidies, and domestic supports; tariffs on } \\
\text { manufactures; and services barriers, clarification of } \\
\text { various WTO rules and agreements }\end{array}$ & \\
\hline
\end{tabular}

Source: “The GATT Years from Havana to Marrakesh” [www.wto.org] 
Table 2

The Boundaries to the WTO Regime

Core disciplines

- Most favored nation (MFN) treatment

- Market access based on reciprocity

- Prohibition of quantitative import restrictions

- Customs valuation and procedures

- Transparency (especially in standards)

- Safeguards

- Antidumping

- Dispute settlement

Present disciplines requiring modification to take legitimate national interests into account

- Domestic subsidies

- TRIMS

- TRIPS

- Government procurement

Preferential trading arrangements that do not inhibit global trade (Article XXIV)

- Customs unions

- Free trade arrangements

- Sectoral arrangements

- Developing country preferences

National regulations for health, safety, and consumer protection

- Countries set their own national standards, without protectionist intent

National regulations wholly beyond WTO boundaries

- Labor and environmental standards

- Regulations affecting service industries exempt from market access negotiations

- Competition policy

Source: Brown and Stern (2006, p. 268). 
Figure 1

Average Tariffs on Manufactures

Selected Years 1913-Post-Uruguay Round

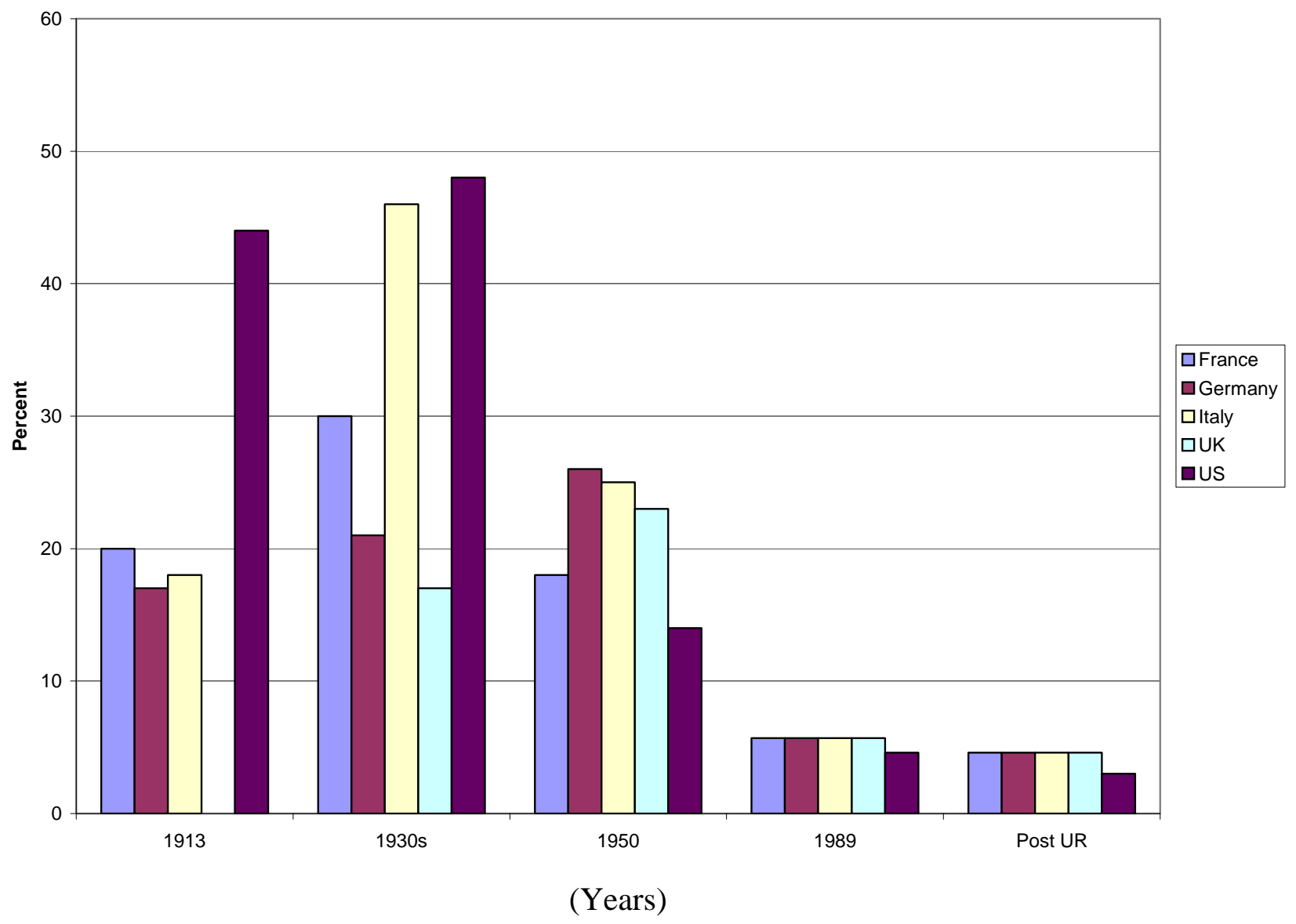

Source: Crafts (2000), Table 2.4, p. 28. 
Figure 2

WTO Dispute Settlement Procedure

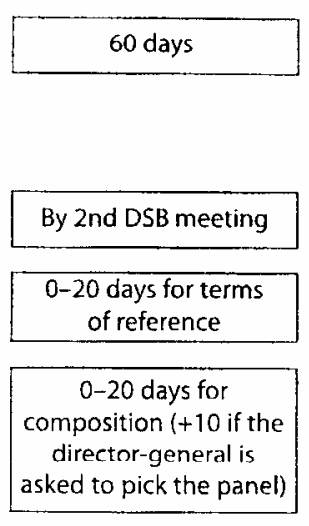

6 months from panel's composition, 3 months if urgent

Up to 9 months from panel's establishment

60 days for panel report, unless appealed

"Reasonable period of
time" determined by:
member proposes, DSB
agrees; or parties in
dispute agree; or arbitra-
tor (approx. 15 months
if by arbitrator)

30 days after "reasonable period" expires

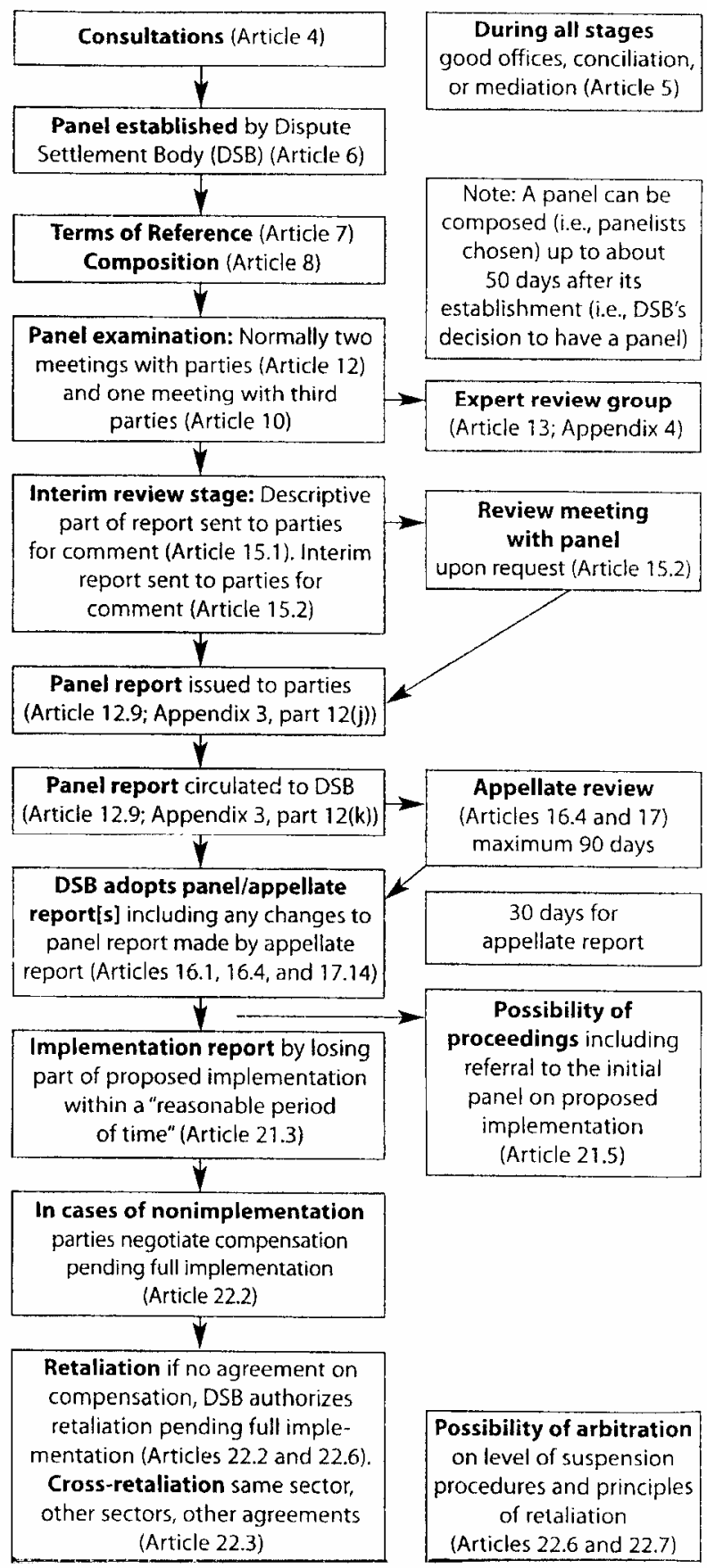

www.wto.org 
Figure 3

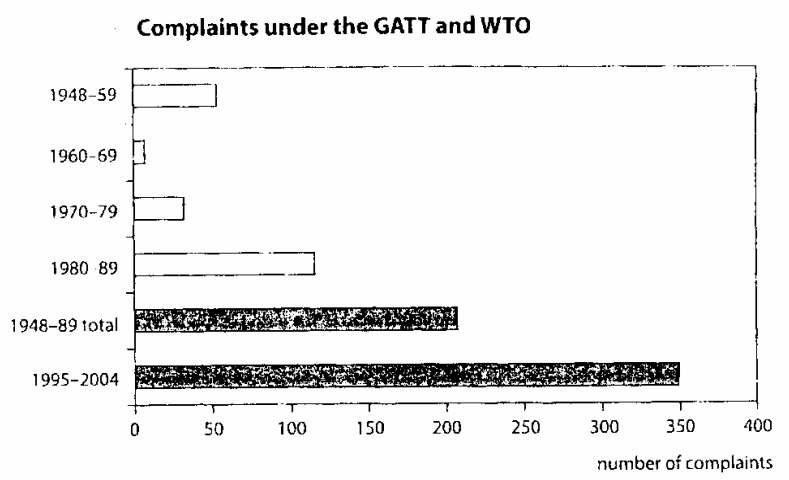

Source: Devereaux, Lawrence, and Watkins (2006, Vol. 2, p. 11). 
Figure 4

Numbers of Dispute Settlement Actions and Dispositions

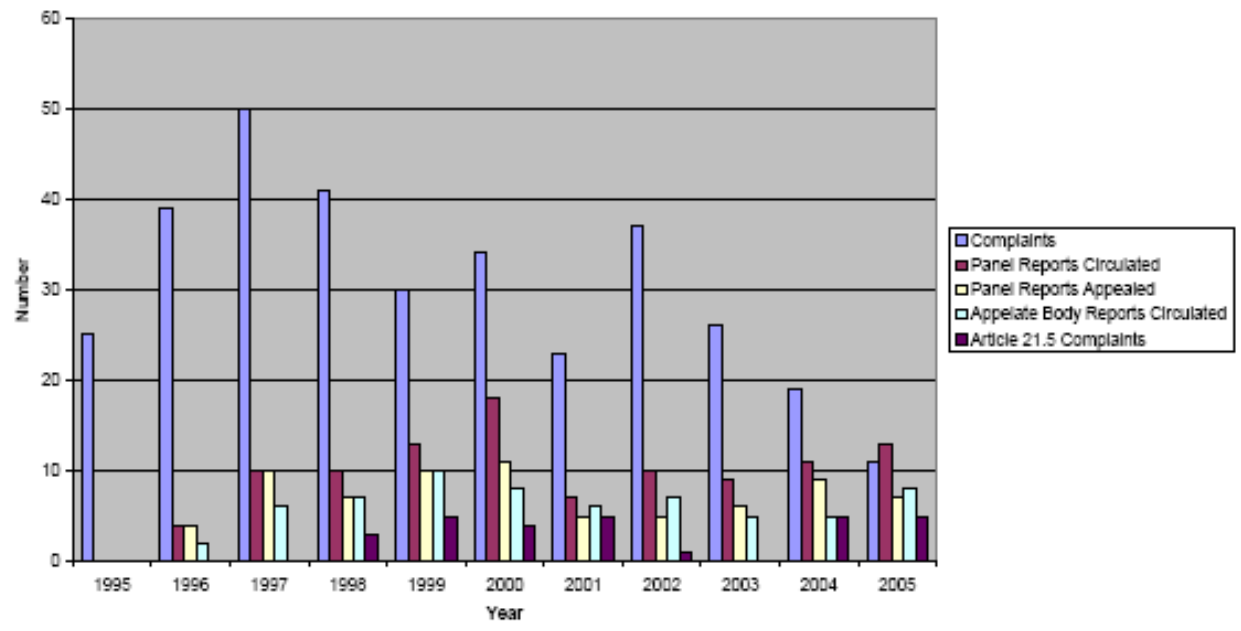

Source: Pelzman and Shohan (2007, p. 20). 
Figure 5

Complaining and Responding Country Concentration

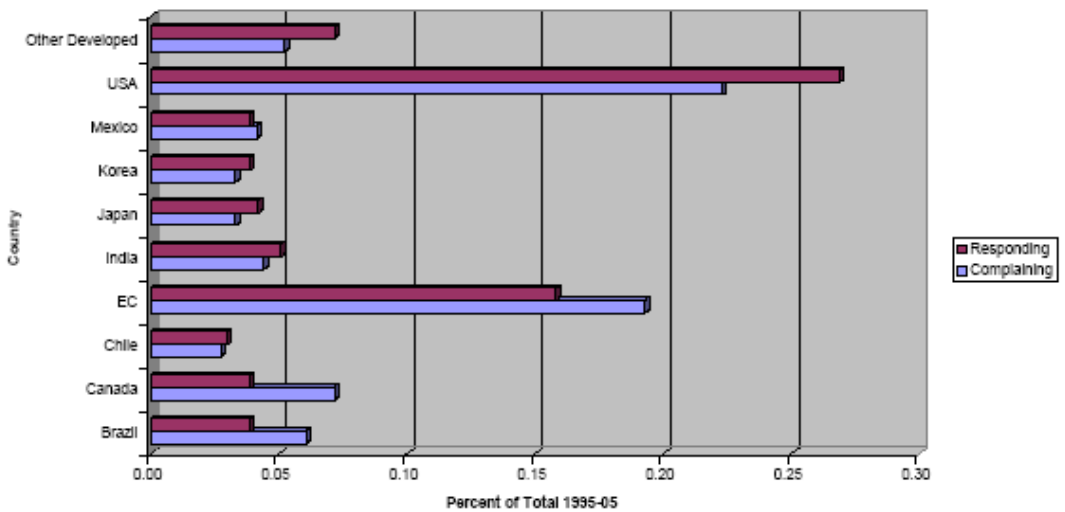

Source: Pelzman and Shohan (2007, p. 21). 